\title{
Cytological Spectrum of Major Salivary Gland Lesions: An Observational
}

\author{
R.Bhuvanamha Devi ${ }^{1 *}$, G.Shivashekar ${ }^{1}$, Hemalatha Ganapathy ${ }^{3}$, Aruna $^{1}$ and Geetha ${ }^{1}$ \\ ${ }^{1}$ Department of Pathology, SRM Medical College Hospital \& Research Centre, Potheri, Chennai, Tamil Nadu, India. \\ ${ }^{2}$ Department of Pathology, Sree Balaji Medical College \& Hospital, Chennai, Tamil Nadu, India.
}

\begin{abstract}
Background: Fine needle aspiration cytology (FNAC) is an accurate, cost effective \& safe technique for diagnosing salivary gland lesions. We conducted this study to observe the cytological spectrum of different salivary gland lesions in two tertiary care hospitals.

Methods: This is a prospective study carried from June 2010 to April 2014 at SBMCH Chromepet and SRM MCH \& RC, Potheri. Fine needle aspiration was performed on patients presenting with complaints of salivary gland lesions. Data was statistically analyzed.

Result: FNAC is performed on total of 135 salivary gland lesions. 11 were non diagnostic aspirate (8.2\%), 58 were non neoplastic lesions $(42.9 \%)$ and 66 were neoplastic lesions (48.9\%). The most common benign tumor of salivary gland is pleomorphic adenoma and mucoepidemoid carcinoma was the most common malignant tumor. The most common major salivary gland involved is parotid gland.

Conclusion: In the present study, neoplastic lesions were more common than non-neoplastic lesions. We conclude that inspite of few diagnostic pitfalls FNAC still plays a vital role in differentiating neoplastic from non- neoplastic salivary gland lesions to provide guideline for appropriate patient management.
\end{abstract}

Keywords: Cytology, FNAC, Salivary Gland, Neoplastic Lesion, Non Neoplastic Lesion.

\section{Introduction}

Salivary glands are exocrine organs. There are three paired major salivary glands \& numerous unpaired minor salivary glands. It is made of lobular architecture of tubuloacinar glands which is well defined by anastomosing connective tissue trabeculae carrying excretory ducts, vascular \& neural branches.

A wide variety of lesions arises from salivary glands. It accounts about $2-6.5 \%$ of all head and neck lesions. Clinical evaluation of salivary gland lesions and arriving at accurate diagnosis is quite a challenging task. Fine needle aspiration cytology (FNAC) is safe reliable, cost effective \& minimally invasive method for evaluating salivary gland lesions owing to its easy accessibility \& superficial location. ${ }^{[1]}$ The characteristic features of various salivary gland lesions are well established in literatures. Therefore, accurate diagnosis is possible in most of the cases. This study was conducted to observe the various cytological spectrum of major salivary gland lesion in two tertiary care hospitals.

\section{Materials and Methods:}

This is 4 year prospective study carried out at Department of Pathology from June 2010 to April 2014 at SBMCH Chromepet and SRM MCH \& RC, Potheri. Patients presenting with complaints of swelling of salivary glands were subjected to FNAC with 23 gauge needle. Their complete clinical history, examination findings and demographic details were recorded. The smears were stained with H\&E, Giemsa \& Papanicolaou stain and was subsequently examined by pathologists. Statistical analysis was done.

\section{Result}

During this study period, a total of 135 salivary gland lesions were sampled by FNAC procedure. 11 were nondiagnostic aspirate (8.2\%). 58 were non-neoplastic lesions $(42.9 \%)$ and 66 were neoplastic lesions (48.9\%). The age of patient ranged from 13 to 88 years. The peak incidence of non-neoplastic $\&$ benign neoplastic salivary gland lesion was noted in the $3^{\text {rd }} \& 4^{\text {th }}$ decade while the peak incidence of malignant tumors was noted in elderly age, $6^{\text {th }}$ decade of life. Overall, slight male preponderance was observed with male to female ratio of 1.5: 1(Table 1).

Non neoplastic lesions were predominantly seen among female patients and neoplastic lesions were commonly seen among the male population. Parotid was the most common salivary gland involved (71\%) involved followed by it was submandibular $(26.6 \%)$ \& sublingual gland $(2.4 \%)$. The most common lesion in parotid gland was benign neoplasm, pleomorphic adenoma (40\%). In submandibular gland, non-neoplastic lesion chronic sialadenitis (12\%) was common. The most common clinical presentation was 
swelling of salivary gland (100\%), followed by pain (17\%) and facial nerve palsy (1.6\%). Among the non-neoplastic lesion, chronic sialadenitis $(21 \%)$ were predominant and among the neoplastic lesion, benign tumor accounts about $44 \%$ the malignant tumor (8\%). Pleomorphic adenoma (37.9\%) was the most common benign neoplasm and Mucoepidermoid carcinoma (4.8\%) was the most common malignant neoplasm.

Cytology diagnosis (Figure 1) of non-neoplastic lesions includes acute sialadenitis $(7.2 \%)$, chronic sialadenitis
(20.9\%), benign cystic lesion (12.4\%), lymphoepithelial lesion (5.6\%) and granulomatous sialadenitis (0.8\%). Cytology diagnosis of benign neoplastic lesions were pleomorphic adenoma (37.9\%), monomorphic adenoma $(3.2 \%)$ and warthin tumor $(3.2 \%)$. Cytology diagnosis of malignancy neoplastic lesions were mucoepidermoid carcinoma $(4.8 \%)$. The adenoid cystic carcinoma, epithelial myoepithelial carcinoma, carcinoma ex pleomorphic adenoma, acinic cell carcinoma and salivary duct carcinoma were each $0.8 \%$.

Table 1: Distribution of non-neoplastic and neoplastic salivary gland lesions.

\begin{tabular}{|c|c|c|c|c|c|c|c|c|}
\hline Diagnosis & M & $\mathbf{F}$ & Pain & $\begin{array}{l}\text { Swel- } \\
\text { ling }\end{array}$ & $\begin{array}{c}\text { Nerve } \\
\text { palsy }\end{array}$ & Parotid & SM & SL \\
\hline $\begin{array}{l}\text { Non neoplastic lesions: } \\
\text { Acute sialadenitis } \\
\text { Chronic sialadenitis } \\
\text { Benign cystic lesions } \\
\text { Lymphoepithelial sialadenitis } \\
\text { Granulomatous sialadenitis }\end{array}$ & $\begin{array}{c}6 \\
15 \\
6 \\
4 \\
1\end{array}$ & $\begin{array}{c}3 \\
11 \\
9 \\
3 \\
0\end{array}$ & $\begin{array}{l}8 \\
4 \\
3 \\
2 \\
0\end{array}$ & $\begin{array}{c}4 \\
26 \\
14 \\
7 \\
1\end{array}$ & $\begin{array}{l}0 \\
0 \\
0 \\
0 \\
0\end{array}$ & $\begin{array}{c}5 \\
10 \\
6 \\
6 \\
1\end{array}$ & $\begin{array}{c}3 \\
15 \\
9 \\
1 \\
0\end{array}$ & $\begin{array}{l}1 \\
1 \\
0 \\
0 \\
0\end{array}$ \\
\hline $\begin{array}{l}\text { Neoplastic lesions (Benign): } \\
\text { Pleomorphic adenoma } \\
\text { Warthin's tumor } \\
\text { Basal cell adenoma }\end{array}$ & $\begin{array}{c}27 \\
3 \\
3\end{array}$ & $\begin{array}{c}20 \\
1 \\
1\end{array}$ & $\begin{array}{l}2 \\
0 \\
0\end{array}$ & $\begin{array}{c}47 \\
4 \\
4\end{array}$ & $\begin{array}{l}0 \\
0 \\
0\end{array}$ & $\begin{array}{c}44 \\
4 \\
4\end{array}$ & $\begin{array}{l}3 \\
0 \\
0\end{array}$ & $\begin{array}{l}0 \\
0 \\
0\end{array}$ \\
\hline $\begin{array}{l}\text { Neoplastic lesions (Malignant): } \\
\text { Mucoepidermoid carcinoma } \\
\text { Adenoid cystic carcinoma } \\
\text { Epithelial myoepithelial carcinoma } \\
\text { Carcinoma ex-pleomorphic adenoma, } \\
\text { Acinic cell carcinoma } \\
\text { Salivary duct carcinoma }\end{array}$ & $\begin{array}{l}6 \\
1 \\
1 \\
0 \\
0 \\
0\end{array}$ & $\begin{array}{l}0 \\
0 \\
0 \\
1 \\
1 \\
1\end{array}$ & $\begin{array}{l}1 \\
1 \\
0 \\
0 \\
0 \\
0\end{array}$ & $\begin{array}{l}6 \\
1 \\
1 \\
1 \\
1 \\
1\end{array}$ & $\begin{array}{l}1 \\
1 \\
0 \\
0 \\
0 \\
0\end{array}$ & $\begin{array}{l}6 \\
0 \\
1 \\
1 \\
0 \\
1\end{array}$ & $\begin{array}{l}0 \\
1 \\
0 \\
0 \\
1 \\
0\end{array}$ & $\begin{array}{l}0 \\
0 \\
0 \\
0 \\
0 \\
0\end{array}$ \\
\hline
\end{tabular}

SM - submandibular gland; SL - Sublingual gland

Table 2a: The cytological features of non - neoplastic salivary gland lesions with differential diagnosis and differentiating features. ${ }^{[1,25]}$

\begin{tabular}{|l|l|l|l|}
\hline Diagnosis & Cytological features & Differential diagnosis & Differentiating features \\
\hline Acute sialadenitis & $\begin{array}{l}\text { Few duct epithelial cells, } \\
\text { neutrophils and necrotic } \\
\text { debris. }\end{array}$ & $\begin{array}{l}\text { Malignant neoplasm with } \\
\text { superadded infection }\end{array}$ & $\begin{array}{l}\text { Scant cellularity and limited or no } \\
\text { atypia. }\end{array}$ \\
\hline Chronic sialadenitis & $\begin{array}{l}\text { Few duct epithelial and acinar } \\
\text { cells, in the background } \\
\text { of proteinaceous material, } \\
\text { fibrous stromal elements and } \\
\text { mature lymphocytes. }\end{array}$ & $\begin{array}{l}\text { Lymphoepithelial lesion } \\
\text { Warthin's tumor }\end{array}$ & $\begin{array}{l}\text { Absence of lymphoepithelial } \\
\text { islands and fragments with } \\
\text { germinal center. } \\
\text { Absence of cohesive clusters of } \\
\text { oncocytes. }\end{array}$ \\
\hline Benign cystic lesions & $\begin{array}{l}\text { Numerous histiocytes, } \\
\text { lymphocytic infiltrates in a } \\
\text { necrotic debris. }\end{array}$ & $\begin{array}{l}\text { Cystic lymphoepithelial } \\
\text { lesion } \\
\text { Cystic mucoepidermoid } \\
\text { carcinoma }\end{array}$ & $\begin{array}{l}\text { Absence of lymphoepithelial } \\
\text { islands and fragments with } \\
\text { germinal center. } \\
\text { Absence of good cellularity, } \\
\text { with atypia and clusters of } \\
\text { intermediate and epidermoid } \\
\text { cells. }\end{array}$ \\
\hline
\end{tabular}




\begin{tabular}{|l|l|l|l|}
\hline Diagnosis & Cytological features & Differential diagnosis & Differentiating features \\
\hline Lymphoepithelial sialadenitis & $\begin{array}{l}\text { Chronic inflammatory cell } \\
\text { infiltrates, lymphoepithelial } \\
\text { islands and fragments with } \\
\text { germinal center. }\end{array}$ & $\begin{array}{l}\text { Chronic sialadenitis } \\
\text { Warthin's tumor } \\
\text { MALToma }\end{array}$ & $\begin{array}{l}\text { Sparsely cellular, fewer } \\
\text { lymphocytes. } \\
\text { Absence of cohesive clusters of } \\
\text { oncocytes. } \\
\text { Absence of numerous } \\
\text { monocytoid B cells. }\end{array}$ \\
\hline Granulomatous sialadenitis & $\begin{array}{l}\text { Epithelioid histiocytic } \\
\text { clusters,inflammatory } \\
\text { infiltrates, multinucleated } \\
\text { giant cell in granular necrotic } \\
\text { debris background. }\end{array}$ & $\begin{array}{l}\text { Chronic sialadenitis and } \\
\text { lymphoepithelial lesions }\end{array}$ & $\begin{array}{l}\text { Presence of epithelioid } \\
\text { histiocytic clusters. }\end{array}$ \\
\hline
\end{tabular}

Table 2b: The cytological features of neoplastic salivary gland lesions with differential diagnosis and differentiating features. $[1,25]$

\begin{tabular}{|c|c|c|c|}
\hline Diagnosis & Cytological features & Differential diagnosis & Differentiating features \\
\hline $\begin{array}{l}\text { Pleomorphic } \\
\text { adenoma }\end{array}$ & $\begin{array}{l}\text { Epithelial, myoepithelial } \\
\text { cells in a chondromyxoid } \\
\text { matrix. }\end{array}$ & $\begin{array}{l}\text { Basal cell adenoma } \\
\text { Adenocarcinoma } \\
\text { Myoepithelioma }\end{array}$ & $\begin{array}{l}\text { Absence of basaloid cells with peripheral } \\
\text { palisading. } \\
\text { Absence of cellular atypia. } \\
\text { Absence of exclusively myoepithelial } \\
\text { cells and presence of chondromyxoid } \\
\text { background. }\end{array}$ \\
\hline Warthin's tumor & $\begin{array}{l}\text { Lymphocytes, oncocytes } \\
\text { in a background of } \\
\text { granular debris. }\end{array}$ & $\begin{array}{l}\text { Lymphoepithelial lesion } \\
\text { MALToma } \\
\text { Oncocytoma }\end{array}$ & $\begin{array}{l}\text { Absence of lymphoepithelial islands and } \\
\text { fragments with germinal center; Presence } \\
\text { of oncocytic clusters. } \\
\text { Absence of numerous monocytoid B cells. } \\
\text { Presence of lymphocytes and absence of } \\
\text { clean background. }\end{array}$ \\
\hline Basal cell adenoma & $\begin{array}{l}\text { Variable sized clusters } \\
\text { of basaloid cells with } \\
\text { peripheral band of } \\
\text { non-fibrillary hyaline } \\
\text { material. }\end{array}$ & $\begin{array}{l}\text { Chronic sialadenitis } \\
\text { Basal cell adenocarcinoma } \\
\text { Adenoid cystic carcinoma } \\
\text { (Solid variant) }\end{array}$ & $\begin{array}{l}\text { Presence of good cellularity with absence } \\
\text { of chronic inflammation. } \\
\text { Absence of malignant features. } \\
\text { Stromal material surrounds tumor cells } \\
\text { instead of tumor cells surrounding stromal } \\
\text { material in adenoid cystic carcinoma. }\end{array}$ \\
\hline $\begin{array}{l}\text { Mucoepidermoid } \\
\text { carcinoma }\end{array}$ & $\begin{array}{l}\text { Mucous cell, epidermoid } \\
\text { cells, and intermediate } \\
\text { cells in the background } \\
\text { of extracellular mucin. }\end{array}$ & $\begin{array}{l}\text { Carcinoma ex pleomorphic } \\
\text { adenoma } \\
\text { Salivary duct carcinoma } \\
\text { Metastatic squamous cell } \\
\text { carcinoma }\end{array}$ & $\begin{array}{l}\text { Absence of high grade malignant cells } \\
\text { with benign component of pleomorphic } \\
\text { adenoma. } \\
\text { Absence of extensive necrosis and } \\
\text { papillary architecture. } \\
\text { Absence of extensive keratinization. }\end{array}$ \\
\hline $\begin{array}{l}\text { Adenoid cystic } \\
\text { carcinoma }\end{array}$ & $\begin{array}{l}\text { Numerous atypical } \\
\text { basaloid cells with three } \\
\text { dimentional acellular } \\
\text { hyaline matrix globules. }\end{array}$ & $\begin{array}{l}\text { Pleomorphic adenoma } \\
\text { Polymorphous low grade } \\
\text { adenocarcinoma } \\
\text { Epithelial myoepithelial } \\
\text { carcinoma }\end{array}$ & $\begin{array}{l}\text { Absence of fibrillary chondromyxoid matrix } \\
\text { with myoepithelial cells. } \\
\text { Absence of normachromatic nucleus } \\
\text { in contrast to hyperchromatic nuclei in } \\
\text { adenoid cystic carcinoma. } \\
\text { Absence of Biphasic cell population, with } \\
\text { plenty of large cell myoepithelial cell and } \\
\text { peripherally located acellular basement } \\
\text { membrane material. }\end{array}$ \\
\hline
\end{tabular}




\begin{tabular}{|l|l|l|l|}
\hline Diagnosis & Cytological features & Differential diagnosis & Differentiating features \\
\hline $\begin{array}{l}\text { Acinic cell } \\
\text { carcinoma }\end{array}$ & $\begin{array}{l}\text { Loosely cohesive } \\
\text { clusters of cells of } \\
\text { serous acinic type } \\
\text { with abundant delicate } \\
\text { vacuolated cytoplasm } \\
\text { and small round to oval } \\
\text { bland nuclei. }\end{array}$ & $\begin{array}{l}\text { Normal salivary gland and } \\
\text { sialadenosis } \\
\text { Oncocytoma and Warthin's } \\
\text { tumor } \\
\text { Mucoepidermoid carcinoma }\end{array}$ & $\begin{array}{l}\text { Absence of tightly cohesive grape } \\
\text { like clusters of acinar cells with ductal } \\
\text { elements. } \\
\text { Absence of finely granular or waxy } \\
\text { cytoplasm. } \\
\text { Absence of mucin in clear acinar cells } \\
\text { and mixture of squamous, mucinous and } \\
\text { intermediate type cells. }\end{array}$ \\
\hline $\begin{array}{l}\text { Carcinoma ex- } \\
\text { pleomorphic } \\
\text { adenoma, }\end{array}$ & $\begin{array}{l}\text { Marked cellular atypia, } \\
\text { necrosis, increase } \\
\text { in mitosis along with } \\
\text { benign component of } \\
\text { pleomorphic adenoma. }\end{array}$ & $\begin{array}{l}\text { Pleomorphic adenoma with } \\
\text { atypia } \\
\text { High grade mucoepidermoid } \\
\text { carcinoma }\end{array}$ & $\begin{array}{l}\text { Absence of overt features of malignancy } \\
\text { Absence of mixture of } \\
\text { squamous,mucinous and intermediate } \\
\text { type cells. }\end{array}$ \\
\hline
\end{tabular}

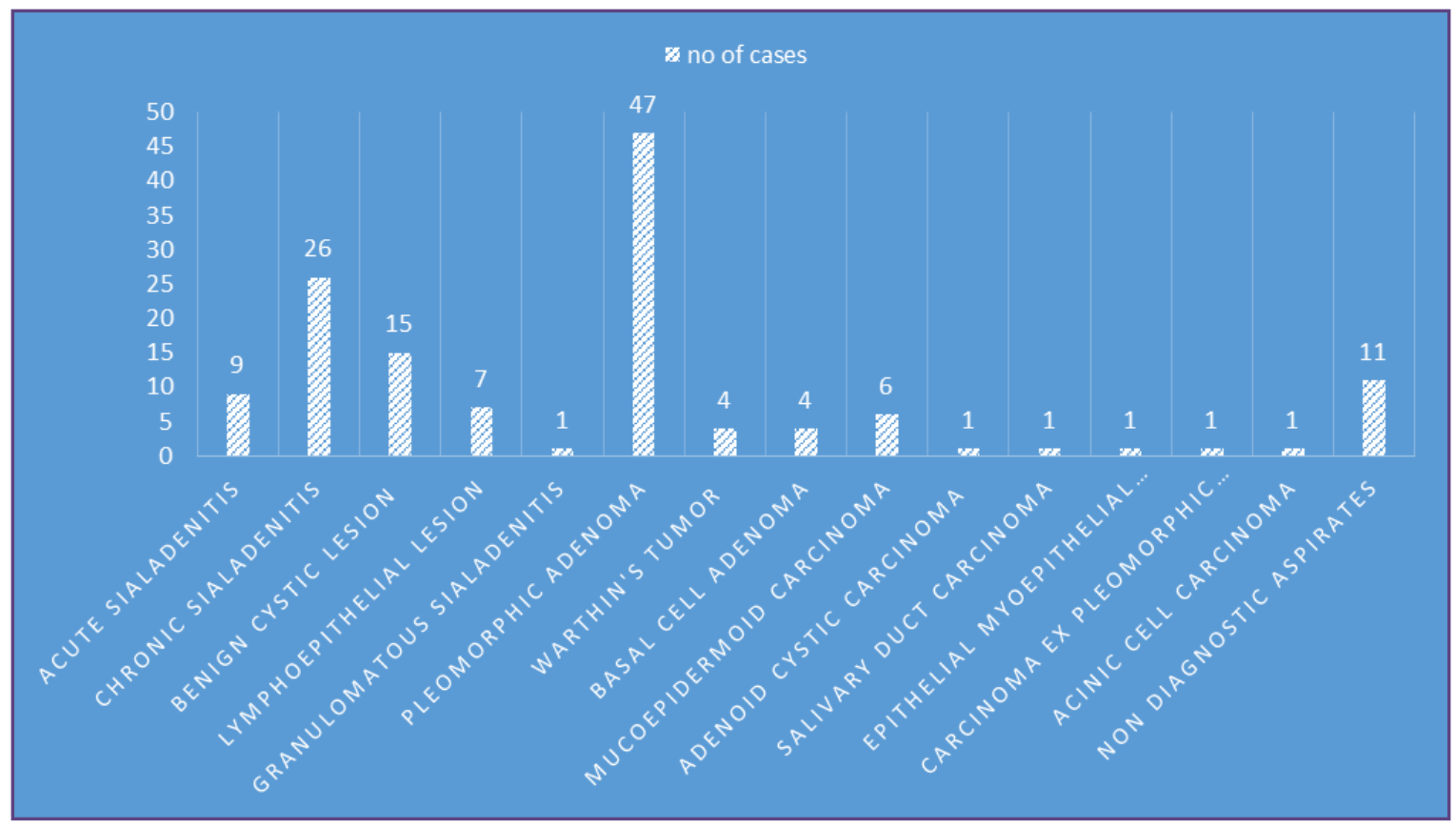

Fig. 1: Cytological diagnosis of salivary gland lesions.

\section{Discussion}

The salivary gland lesion constitutes only a small proportion of head \& neck cytology, however, wide variants of lesions encountered in the salivary gland makes it an interesting task in FNAC diagnosis. FNAC, is a minimally invasive preoperative diagnostic tool, which serves to determine the native of the lesion that provides guideline for clinician to appropriately manage the patient.

In the present study, 135 cases of salivary gland lesion were subjected to FNAC; of which 11 cases were non diagnostic aspirate of acellular hemorrhagic aspirate (8\%), which falls within range of $3-12 \%$ of non-diagnostic rate reported in literatures. ${ }^{[2-6]}$ Few authors have suggested that non representative aspirates could be minimized by
FNAC being performed by experienced cytotechnologist and by avoiding sampling errors with the help of radiology guidance. ${ }^{[7,8]}$

In the present study the proportion of non-neoplastic lesion is $48 \%$ comparable with incidence of non-neoplastic lesion described in medicine literature which ranges between 20-61.6\%. ${ }^{[9,10]}$ Neoplastic lesion $(48.9 \%)$ were the most common condition for which salivary gland were needled. The benign tumors outnumber the malignant tumor with the ratio of 1: 5. Similar ratio, was observed by Vaidhya et $\mathrm{al}^{[11]}$, Dhanlakshmi et $\mathrm{al}^{[12]}$, Akhtar et $\mathrm{al}^{[13]}$, whereas Aruna et a ${ }^{[14]}$, observed higher incidence of non-neoplastic lesions in parotid gland. In developing countries like India, patients postpone their approach to clinicians, until the 
clinical symptoms, especially with neoplastic lesions, are unbearable and cosmetically not appealing.

In our study, the age group affected range from 13 to 88 years with the mean age of 43 years and had slight male preponderance (59\%). The non-neoplastic \& benign lesion were seen more common in $3^{\text {rd }}-4^{\text {th }}$ decade whereas the malignant lesion was seen in $5^{\text {th }}-6^{\text {th }}$ decade of life. This is in concordance with Ameli et al ${ }^{[15]}$ study. Parotid gland was the most common site for all the salivary gland lesion followed by submandibular gland and sublingual gland. The similar findings were observed by Verma et al ${ }^{[16]} \&$ Sengupta et al. ${ }^{[17]}$

Among the non-neoplastic lesions, chronic sialadenitis was the most common lesions $(20.9 \%)$. It is comparable with the incidence reported by Vaidhya et al $(18.9 \%)^{[11]}$ and Das et al $(34.4 \%)$. ${ }^{[24]}$

Among the benign neoplasm, pleomorphic adenoma $(37.9 \%)$ was the most common lesion with increased incidence of occurrence in parotid gland $(71.7 \%)$ in the present study, similar observation was noted by Masanja et al $^{[18]} \&$ Sunida et al. ${ }^{[19]}$

Among the malignant salivary gland neoplasm. Mucoepidermoid carcinoma was reported in $4.8 \%$ cases. It was the most common of all malignant tumour in our study. Similar observation was made by Flavia et al ${ }^{[20]}$ and Muhammed Isakara et al. [21] One each case of adenoid cystic carcinoma, epithelial myoepithelial carcinoma, carcinoma ex pleomorphic adenoma, acinic cell carcinoma and salivary duct carcinoma were reported in the study. Their incidence is comparable to that of other studies. ${ }^{[16,}$ 19, 22, 23] The cytological features of the non-neoplastic and neoplastic lesions encountered in this study, along with their mimickers and how we differentiated are tabulated (Table 2a \& 2b).

FNAC plays a pivotal role in providing preoperative diagnosis which helps clinician in planning further management of patient whether to treat conservatively or to subject the patient for surgery. It is essential to note that FNAC eliminates unnecessary surgery in about one third cases. ${ }^{[22]}$

\section{Conclusion}

The present study summarizes the data available on cytological spectrum of salivary gland lesions in tertiary care hospitals in terms of frequency, site of occurrence patient demographics and emphasis the critical examination of cytological smears with the knowledge mimickers and the differentiating features. FNAC of salivary gland lesions is a primary diagnostic tool and it is easy, reliable screening method to differentiate neoplastic from non-neoplastic lesions, thus eliminating the risk of surgical morbidity in non-neoplastic conditions.

\section{Acknowledgements}

Department of Pathology of Sree Balaji Medical College \& Hospital and SRM Medical Hospital \& Research Centre.

\section{Reference}

1. Orell SR, Kilijanienko J. Head and Neck; Salivary Glands. In : Orell SR, Sterrett GF, eds. Orell and Sterrett's Fine Needle Aspiration Cytology. 5th ed. Edinburg: Churchill Livingstone; 2012:53-77.

2. Mihashi H, Kawahara A, Kage M, Kojiro M, Nakashima T, Umeno H, Sakamoto K, Chiziwa H, Kurume. Comparison of preoperative fine-needle aspiration cytology diagnosis and histopathological diagnosis of salivary gland tumors. Med J. 2006; 53(1-2):23-7.

3. Jayaram G, Verma AK, Sood N, Khurana N. Fine needle aspiration cytology of salivary gland lesions. J Oral Pathol Med. 1994 Jul; 23(6):256-61.

4. Wada E, Kounoike Y, Kinoshita Y, Ohashi I, Yuba Y, Kobashi Y. Fine needle aspiration cytology of salivary gland. J Jpn Soc Clin Cytol. 2004;43:155-60.

5. Nguansangiam S, Jesdapatarakul S, Dhanarak N, Sosrisakorn $\mathrm{K}$. Accuracy of fine needle aspiration cytology of salivary gland lesions: routine diagnostic experience in Bangkok, Thailand. Asian Pacific Journal of Cancer Prevention. 2012;13(4):1583-8.

6. Tan LG, Khoo ML. Accuracy of fine needle aspiration cytology and frozen section histopathology for lesions of the major salivary glands. Annals of the Academy of Medicine Singapore. 2006;35(4):242-8.

7. Akbaş. Y, E. U. Tuna, A. Demireller, H. Ozcan, and C. Ekinci, "Ultrasonography guided fine needle aspiration biopsy of parotid gland masses," Kulak Burun Bogaz Ihtisas Dergisi, 2004;13:15-18.

8. Pratap. R, Qayyum, Ahmed, Jani, and Berman LH, "Ultrasound-guided core needle biopsy of parotid gland swellings," Journal of Laryngology and Otology, 2009;123:449-452.

9. Rajwanshi A, Gupta K, Gupta N, Shukla R, Srinivasan R, Nijhawan R, Vasishta R. Fine-needle aspiration cytology of salivary glands: diagnostic pitfalls--revisited. Diagn Cytopathol. 2006 Aug; 34(8):580-4.

10. Ashraf A, Shaikh AS, Kamal F, Sarfraz R, Bukhari MH. Diagnostic reliability of FNAC for salivary gland swellings: a comparative study. Diagn Cytopathol. 2010 Jul; 38(7):499504.

11. Vaidhya S, Sinha A, Narayan S, Adhikari Sabira. A comparative study of fine needle aspiration cytology and histopathology in salivary gland lesions. JPN, 2011; 1:108113. 
12. Dhanalakshmi M, Lakshmana Rao, Krishnaswamy, Manohar, Gopalakrishnan, Aruna. Fine needle aspiration cytology and histopathology of salivary gland lesions: A correlative study in rural teaching hospital. JCCM 2009; 12: $674-680$.

13. Akhter J, Hirachand S, Lakhey M. Role of FNAC in the diagnosis of salivary gland swellings. KUMJ 2008; 6: 204 -208 .

14. Aruna S, Prathiksha Pai, Shreekant K. Kittur. Cytomorphological study of major salivary gland lesions: a 5-year experience at a tertiary care center. Medica Innovatica. 2016;5 (1):13-19.

15. Ameli F, Baharoom A, Md Isa N, Noor Akmal S. Diagnostic challenges in fine needle aspiration cytology of salivary gland lesions. Malays J Pathol 2015 Apr 37(1): 11-8.

16. Verma S. Fine needle aspiration cytology of salivary gland lesions: study in a tertiary care hospital of North Bihar. Int J Res Med Sci 2016;4:3869-72.

17. Sengupta Sengupta S, Roy A, Mallick et al. FNAC of salivary glands. Indian J Otolaryngol Head Neck Surg 2002;54:184-8

18. Masanja MI, Kalyanyama BM and simon ENM. Salivary gland tumors in Tanzania. East African Medical Journal 2003; 80 (8): $429-431$.
19. Sunida R, Jongkolnee settakorn, Ponsak Mahanupab. Salivary gland tumours in Maharajnakorn Chiang Mai Hospital : A retrospective study of 198 cases. CMMB 2006; 45(2): 45-53.

20. Flavia A. Salivary gland tumor: A review of 599 cases in a Brazialian population. Head and neck pathol, 2009; 3: 271 -275 .

21. Muhammed Isa Kara, Fahrettin goze, Seref ezirganh, Serkan polat. Neoplasms of the salivary glands in a Turkish adult population.Med Oral Pathol Oral Cir Bucal, 2010; 15(6): e $880-885$.

22. Kotwal M, Gaikwad S, Patil R, Munshi M. Fnac of salivary gland- a useful tool in preoperative diagnosis or a cytopathologist's riddle. Journal of cytology. 2007;24(2):858.

23. Iqbal M, Anwar K, Ihsanullah, Mohammad J khan IA, Hussain G. The diagnostic value of FNAC in masses of salivary glands. JPMI 2011; 25: $73-77$.

24. Das K Dilip, Petkar A Mahir, Al Mane M Nadre, Sheik A Zafar and Malik K Mrinmay. Role of fine needle aspiration cytology in the diagnosis of swellings in the salivary gland regions: A study 712 cases. Med Princ Pract 2004; 13: 95 - 106.

25. Edmund S.Cibas, Barbara S. Ducatman. Cytology-diagnostic principles and clinical correlates. 3/e. 2008: 285-318.

*Corresponding author:

Dr. R.Bhuvanamha Devi, MBBS , MD (Pathology), Postal Address: 63, Luxmi Nagar, Naidu shop street, Chromepet, Chennai, Tamil Nadu, India - 600044. Phone: +91 8148840658

Email: drrbdevipath@gmail.com

Financial or other Competing Interests: None. 